\title{
THE RELATIONSHIP BETWEEN THE OWNERSHIP STRUCTURE OF BANKS AND THEIR FINANCIAL PERFORMANCE: EMPIRICAL RESEARCH FOR TURKEY
}

\author{
Mustafa Kevser and Bilge Leyli Elitaş* \\ Faculty of Economics and Administrative Sciences, Yalova, Turkey
}

The aim of this study is to analyze the effects of the ownership structures of banks on their financial performance. The quarterly data of the 13 banks listed on the Istanbul Stock Exchange (BIST) were used for the period from 2005 to 2017. In the study, return on assets (ROA), return on equity (ROE), Tobin's $\mathrm{Q}$ ratio $(\mathrm{TOBIN})$, earnings per share $(\mathrm{EPS})$ and the price/earnings ratio $(\mathrm{P} / \mathrm{E})$ were used for the financial performance indicators. Family ownership, corporate ownership, managerial ownership, foreign ownership, the largest shareholder's ownership, the ownership of the three largest shareholders, and the free-float rate were selected as the independent variables for the study. The leverage ratio, the total assets and the age of the banks were benefited from as the control variables. There are five models formed to analyze the relationship between the variables, and a regression analysis was carried out. The analyses point out the fact that the ownership structures of the banks have an effect on their financial performance. Besides, the results obtained by these analyses are suggested to be coherent for the agency theory as one of the fundamental theories of this subject.

Keywords: ownership structure, financial performance, agency theory, banking, corporate management

JEL Classification: G10, G32

\section{INTRODUCTION}

The financial performances of the economic ownerships operating in the national and international dimensions have become more considerable due to globalization worldwide. As a consequence of increasing competition, accounting

* Correspondence to: B. L. Elitaş, Yalova University, Faculty of Economics and Administrative Sciences, International Trade and Finance Department, Yalova, Turkey;

e-mail: bilgeleyli@gmail.com scandals and the uncertainty of the economic policy, financial crises directly affect business activities and financial performances. The economic structures adapted to developments can survive while others stop operating. There are various factors affecting the financial performance of the banks since the effect of the ownership structure concept (which is studied within the corporate management framework and activities) on financial performance is a substantial argument in the developing world economy. 
Corporate management is a set of institutional and market-based mechanisms deciding on business operations beside urging managers to protect shareholders' profits and also to increase the firm's market price (Denis and McConnel, 2003, 1-2).

The ownership structure concept is a substantial tool of the corporate management mechanism for displaying the suppliers of the firm's capital and indicating each size of shares (İzciler, 2014, 6). The mentioned concept is embodied in the two major components, namely those defined as the ownership identity and ownership concentration. The ownership identity concept denotes (a) substantial shareholder(s) who has/have an influence on the firm's management, whereas the ownership concentration concept implies the collection of the major shares by a single investor or several persons (Grob, 2006, 10).

Several classifications related to ownership identities are existent in the literature, but generally speaking, family ownership, corporate ownership, managerial ownership, and foreign ownership are included in ownership identities. The classifications constantly benefiting from the ownership concentration concept are the ownership of the three largest shareholders and the free-float rate.

Certain financial performance indicators are used to analyze the relationship between the ownership structure of the banks and their financial performance. These are return on assets (ROA), return on equity (ROE), Tobin's $Q$ ratio (TOBIN), earnings per share (EPS) and the price/earnings ratio (P/E). The ownership types analyzed in the study demonstrate various effects on the financial performance indicators. Corporate governance implementation and separate forms of legal protection among the states, as well as economic, juristic, social and cultural diversities among them, cause the effects to vary for each country.

The research study on the relationship between the ownership structure and financial performance is based on the fundamental theories known as agency theory, representation theory and stakeholder theory. Agency theory is one of the most important theories, which implies the appointment of another person in order for such a person to do his/her own business, as well as an analysis of the relationship between them. The relationships between groups, such as shareholders and managers, managers and employers, shareholders and employers, etc. are included within the framework of agency theory although the mentioned theory is based on the maximization of an individual benefit. Hereupon, the principle/agent matter exists between the counterparts of a business and the parties trying to maximize their own profits. Representation theory claims the presence of accordance between the profits of managers and those of shareholders. It denies the agency theory that mentions a differentiation between the profits of managers and those of shareholders, contrary to a consensus existing between them. According to stakeholder theory, mutual benefits are generated between the stakeholders of a business, and the corporate management approach including solely the relationship between shareholders and managers is not sufficient. So, all the groups related to the business should be taken into account by the management.

This study is aimed at determining the effects of the ownership structure of the banks operating on the Istanbul Stock Exchange on their financial performances. In the study, five dependent variables are used as the financial performance indicators. These are: return on assets (ROA), return on equity (ROE), Tobin's $\mathrm{Q}$ ratio (TOBIN), earnings per share (EPS) and price/earnings ratio (P/E). Family ownership, corporate ownership, managerial ownership, foreign ownership, the largest shareholder's ownership, the ownership of the three largest shareholders, and the free- float rate are selected as the independent variables for the purpose of the study. The five hypotheses were formed and regression analysis was conducted in order to analyze the relationships between the variables.

The quarterly data relating to the 2005-2017 period pertaining to the banks listed on the Istanbul Stock Exchange (BIST) are applied in the study. The financial reports of all the businesses listed on BIST constantly since the year 2005 are included due to the Turkish Financial Reporting Standards (compatible 
with the International Financial Reporting Standards) so that the necessary uniform manner is achieved.

The study is divided into six chapters, namely: The Introduction, The Literature Review, The Aim and the Methodology, The Empirical Results, The Results, and The Conclusion.

\section{LITERATURE REVIEW}

Various results have been obtained by the studies analyzing the relationship between the ownership structure and the performance of a business. The various market conditions of the countries, the periods and the aims of the studies are suggested as the basic reasons for obtaining different results. Furthermore, differences in the economic, legal, social and cultural backgrounds between countries, corporate governance, as well as legal protection levels may cause the mentioned variety.

Besides, the ownership structure is investigated in the context of corporate governance. Agency theory, stakeholder theory, stewardship theory, managerial hegemony theory, myopic market theory and resource dependence theory are the theories explaining corporate governance and the ownership structure. So, some of the studies on the relationship between the ownership structure and financial performance related to these theories are presented hereinafter.

Apart from these, ownership concentration is an important part of the ownership structure. In previous studies, the ownership structure used to be examined under many different types. In the studies presented below, ownership concentration is also brought into relationship with these theories.

The first study relating to the effect of the ownership structure on the financial performance of a firm was conducted by A. A. Berle and C. G. Means (1932), who investigated the relationship between the roles of professional managers/the disorganized ownership structure and a firm's performance. They found a reverse correlation between the disorganized ownership structure and financial performance in their mutual study. Hence, a rise in ownership concentration may cause a decrease in the manager's role and control, so that a negative relationship emerges between the ownership concentration and the financial performance of a business.

A. Micco, U. Panizza and M. Yañez (2004) investigates the relationship between a bank's ownership structure and its financial performance both for developing and for developed countries. In this study, the differences between developed and developing countries were determined in terms of financial performance. Developed countries are expected to be much more profitable than developing ones. The study applies the data related to 111 banks for the time period from 1995 to 2002, were subjected to analysis within the study and the regression models for the estimation of the relationship between the variables were formed. Return on assets, return on equity, the interest margin and non-performing loans were used as the financial performance indicators. The variables for the ownership structure were selected as follows: foreign ownership, public ownership and private ownership for the purpose of doing the research. According to the results of the study, no significant relationship was found between the ownership of the bank and its financial performance, when developed countries are concerned; however, statistically significant relationships were detected in the cases of developing countries. In addition, the common banks were evaluated to operate at lower profits comparing with the private ones owing to their higher costs and non-performing loans in developing countries. However, the banks with foreign ownership in developing countries operated with lower costs and higher profitability. While no significant relationship was found between the interest margin and the ownership structure, non-performing loans were evaluated to exist at a higher rate for the common banks in comparison with the private sector.

In their study, C. Tanriöven, İ. Küçükkaplan and E. S. Baş̧̧ (2006) investigate the relationship between ownership and financial performance indicators via variance analysis for the banks listed on BIST, simultaneously trying to find the answer to this question by doing a $\mathrm{t}$ test: "If the general manager 
is also a member of the Board or an owner of the capital, does that affect the performance indicators?" Therefore, the findings of this study have importance in terms of agency theory. They used the quarterly data for the period between the years 1997 and 2001 in the study. Return on assets, return on equity and Tobin's Q ratio were selected as the financial performance indicators, whereas the independent variables were family ownership, holding ownership, and disorganized ownership. As a result of the study, the financial performance indicators varied due to the different ownership types. While the difference with respect to financial performance was lower between family and holding ownerships, it was evaluated that there was an even greater difference between disorganized capital ownership and the financial performance indicators.

E. Berezneak (2007) investigates the relationship between the ownership structure of the banks and their financial performance within the framework of corporate management. The ownership structure is an important part of corporate governance. Therefore, this study was conducted within the scope of corporate governance. In this study, the direct regression method was used in order to analyze the data pertaining to the period from 2003 to 2005. In the study, the financial performance indicators applied were return on assets, return on equity, the net interest margin, and the non-performing loans ratio. The selected dependent variables in the research study were as follows: ownership concentration, public ownership, family ownership, holding ownership, foreign ownership, and the disorganized ownership structure. The size of the bank and capital adequacy were benefited from as the two control variables used in the study. According to the results obtained, the return-on-assets ratio was higher for the banks in foreign ownership, whereas the return on equity and the interest margin ratios were found to be higher in the common banks.

M. Kosak and M. Cok (2008) investigate in their study the relationship between the bank's ownership structure and its financial performance for six Eastern European countries (Croatia, Bulgaria, Romania, Serbia, Macedonia and Albania). They used the data for the period from 1995 to 2004 period. The panel data analysis method was benefited from and the relationships between the variables were estimated by the fixed effect regression models. The return on assets, return on equity, net interest margin and total return on assets before tax ratios were used as the financial performance indicators in the study. Foreign ownership and local ownership variables were included in the ownership structure. According to the results obtained, no significant relationship was found between the financial performance and the ownership structure (with respect to both foreign and local ownerships); however, a significant relationship was detected between the net interest margin and foreign ownership, as well as local ownership (the ownership structure).

I. Antoniadis, T. Lazarides and N. Sarrianides (2010) investigated the relationship between the bank's ownership structure and its financial performance in the context of Greece. The data of the 15 banks listed on the Greece Stock Exchange for the 20002004 period were subject to analysis in the study. Panel data analysis methods were used and the relationships between the variables were estimated by applying fixed effect regression models. The return on assets and return on equity ratios were benefited from as the financial performance indicators in the study. The largest shareholder's capital portion was used herein as the ownership structure variable. In this study, whether ownership concentration had a positive impact or not was the subject matter of the examination. A higher concentration was suggested to be causing lower profitability (Berle \& Means, 1932). According to the results obtained, a statistically significant, but non-linear, relationship was found to exist between both the return on assets and the return on equity ratios and the ownership structure. Concentration in the ownership structure first caused a decline in the return-on-assets ratio and the returnon-equity ratio as well, which was then followed by an increase in the financial performance indicators due to the concentration rise.

N. Kobiessi and X. Sun (2010) studied the relationship between the ownership structure of a bank and its financial performance. The data pertaining to the 249 
banks operating in the MENA region were analyzed for the period between 2000 and 2002. The return on assets and return on equity ratios were used as the financial performance indicators. Besides, foreign ownership, common ownership and local ownership were benefited from as the ownership structure variables in the study. As a result of the research, a statistically significant and positive directional relationship was found to exist between the foreign ownership structure and the return on assets and return on equity ratios. Herein, the mentioned return on assets and return on equity ratios of the local banks were higher than those of the common banks. Another result of the study revealed that the performances of the banks listed on the stock exchange were higher than the performances of the other banks. Additionally, the financial performances of the private banks in foreign ownership proved to be better comparing to the other ownership types. Herein, the common banks demonstrated the least financial performance in the study.

W. Wen (2010) investigated the relationship between the ownership structure and the financial performance of the Chinese banking sector. The data pertaining to a total of 49 Chinese banks were analyzed in the period from 2003 to 2008 . The panel data analysis method was benefited from and the relationships between the variables were estimated via regression models. The return on assets and return on equity ratios were used as the financial performance indicators in the study. Common banks, commercial-deposit banks, city commercial banks, and the five largest shareholders' portion were included in the study as the ownership structure types. According to the results of the research study, the ownership concentration of the common banks demonstrated a significant and positive directional relationship with the return-on-equity rate, whereas a significant, but negative directional relationship was revealed with respect to return on assets.

R. M. Kiruri (2013) investigates the relationship between the ownership structure and the financial performance of the banks within the framework of the Kenyan banks. The data of the 43 banks operating in Kenya were analyzed for the period 2007-2011. Linear regression and correlation analyses were carried out in the study. The return-on-equity rate was benefited from when the financial performance was concerned. Foreign ownership, common ownership, local ownership and the five largest shareholders' portion were included in the study as the ownership structure variables. According to the results obtained, all of the ownership structure variables had a significant effect on the return-on-equity ratio. The five largest shareholders' portion and common ownership affected the return-on-equity rate in a negative direction. However, foreign ownership and local ownership had a positive effect on the returnon-equity ratio.

G. A. Bopkin (2013) analyzes the relationship between the ownership structure and a bank's financial performance. The data belonging to the 25 banks operating in Ghana were studied by applying panel data analysis for the 1999-2007 period. The loan-loss-provision ratio, as well as the return-onassets rate, were used as the financial performance indicators in the study. Foreign ownership, local ownership and insider ownership were benefited from as the variables of the ownership structure. As a result of the conducted study, a statistically insignificant relationship was found to exist between the ownership structure variables and the returnon-asset ratio. The banks in foreign ownership were found to be operating more efficiently and profitably in comparison with the local banks. Additionally, insider ownership had a negative directional effect on the costs and efficiency, according to the study. Besides, the size of the Board had a significant and positive directional relationship with profitability, efficiency and asset management. Also, the banks with a larger size of capital were found to be more profitable; however, they were suggested to have a lower credit quality.

In their study, H. S. Nguyen, T. T. T. Tran, X. C. Dinh, A. N. Lai and B. K. Pham (2015) investigated the effect of the ownership structure on a bank's financial performance. The data pertaining to the 44 banks operating in Vietnam were analyzed for the 20102012 period, and the regression analysis method was applied. Herein, the financial performance indicators 
detected were return on assets and return on equity; besides, foreign ownership, local ownership, common ownership and private ownership were benefited from as the ownership structure variables. In addition, the five largest shareholders' portion was also included in the study as the ownership concentration variable. According to the results of the study, capital concentration had a substantial effect on the returnon-assets ratio. Apart from that, a significant and positive directional relationship was found to exist between the variables. Additionally, yet another significant and positive directional relationship was detected between capital concentration and the return-on-equity rate.

In their study, N. M. Tükenmez, A. G. Gençyürek and C. Ç. Kabakc1 (2016) analyzed the relationship between capital concentration and financial performance. The data relating to the 11 banks operating in Turkey were analyzed via the panel data method for the 2008-2014 period. Herein, the rates of return on assets, return on equity, and total loans/total assets, and Tobin's $Q$ ratio were applied as the financial performance indicators, while simultaneously the largest shareholder's portion and the free-float rate were benefited from as the ownership concentration variables in the study. The age of a bank was used as the control variable within the analysis. According to the results obtained, only one significant and negative directional relationship was found to exist between the largest shareholder's portion and the return-on-assets ratio. So, this finding was brought into relationship with ownership concentration and agency theory. No relationship was detected between the free-float rate and return on assets, return on equity, and Tobin's $Q$ ratio. The age of a bank as the control variable had a negative directional relationship with the return-on-assets and return-on-equity ratios.

In their study, B. L Elitaş, M. Doğan and M. Kevser (2017) investigated the relationship between the ownership structure and financial distress. They analyzed the data belonging to the 112 enterprises listed on the BIST Industrials Index for the 20092015 period. The study's independent variable, and a financial distress indicator, was the Altman Z-Score. The five largest shareholders' portion, corporate ownership, foreign ownership, the leverage ratio, the size of a firm and the free-float rate were included as the independent variables. As a result of the developed robust estimator, ownership concentration and the free-float ratio showed to have negative relationships with financial distress; in contrast, however, there is a positive relationship between corporate ownership and financial distress. Additionally, no statistically significant relationship was detected between foreign ownership and financial distress in the study.

\section{THE AIM AND THE METHODOLOGY}

This study is aimed at analyzing the relationship between the ownership structure and the financial performance of the banks listed on the Istanbul Stock Exchange (BIST). The quarterly regular data of the 13 banks listed on BIST are applied relating to the 2005-2017 period; 52 terms were analyzed in total and 676 observations were obtained. The mentioned data pertaining to the banks were obtained via annual reports, independent audit reports, the Finnet financial analysis program, and the Central Securities Depository (CSD) of Turkey.

Regression analysis was carried out in order to analyze the relationships between the variables. Herein, regression analysis was benefited from applying it to detect the relationships between the variables with a cause-result relationship and to estimate the topic by using these relationships or to make conclusions.

The following models and hypotheses were developed so as to reveal the relationship between the ownership structure of the banks and their financial performances within the framework of the aim set, and the content of the study; thus, study has made an effort to explain the effect of the ownership structure on a bank's financial performance (Figure 1).

The following five hypotheses were formulated and analyzed in the study:

H1: The ownership structure has an effect on a bank's return-on-assets ratio. 


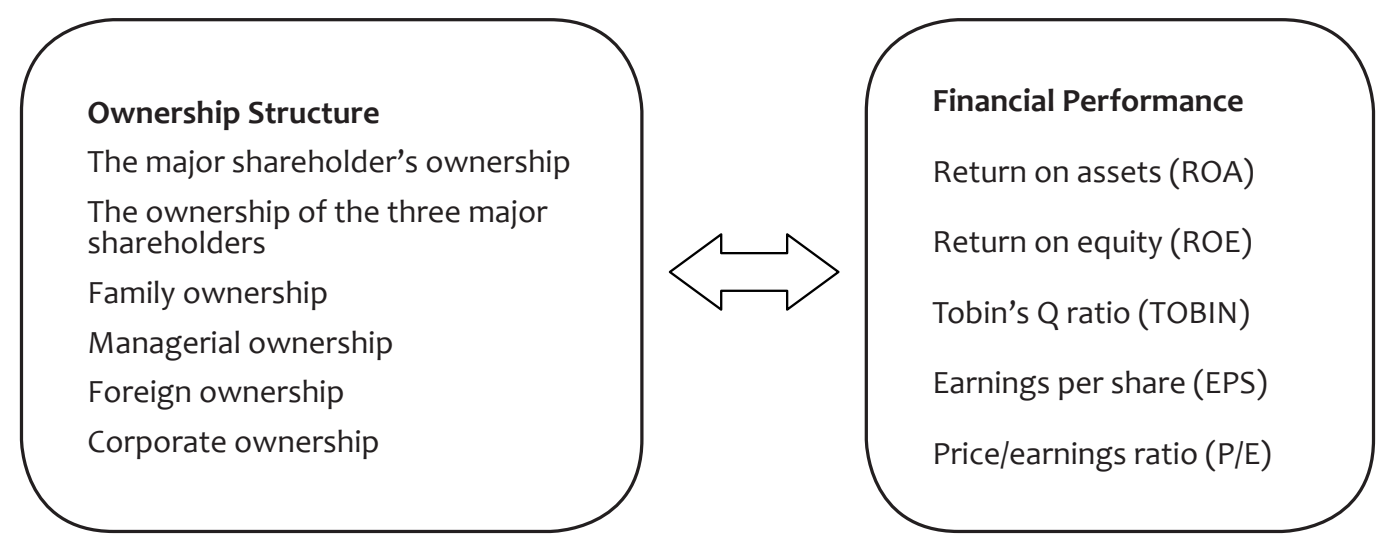

Figure 1 The research model

Source: Authors

H2: The ownership structure has an effect on a bank's return-on-equity ratio.

H3: The ownership structure has an effect on Tobin's Q ratio.

H4: The ownership structure has an effect on the earnings-per-share ratio.

H5: The ownership structure has an effect on a bank's price/earnings ratio.
A total of 15 variables are used in the study; 5 of them are dependent, and 7 variables are independent, whereas 3 of them are the control variables (Table 1). The dependent variables (the financial performance indicators) of the study are the following ratios of return on assets, return on equity, Tobin's $Q$ ratio, earnings per share and price/earnings. The independent variables are family ownership, managerial ownership, foreign ownership, corporate

Table 1 The research variables benefited from in the study

\begin{tabular}{|c|c|c|}
\hline Variables & Definitions & Codes \\
\hline \multicolumn{3}{|l|}{ Dependent Variables } \\
\hline Return on Assets Ratio & Net Profit / Total Assets & ROA \\
\hline Return on Equity Ratio & Net Profit / Total Equity & ROE \\
\hline Tobin's Q Ratio & Market Price / Book Value & TOBIN \\
\hline Earnings per Share Ratio & Net Profit / Number of Shares & EPS \\
\hline Price / Earnings Ratio & $\begin{array}{l}\text { Year-End Market Price of the Shares / Net Profit for } \\
\text { the Period/Number of Shares }\end{array}$ & $\mathrm{P} / \mathrm{E}$ \\
\hline \multicolumn{3}{|l|}{ Independent Variables } \\
\hline The Major Shareholder's Ownership & The Major Shareholder's Equity / Total Equity & LARGEST \\
\hline Ownership of the Three Major Shareholders & The Three Major Shareholders' Equity / Total Equity & LARGEST3 \\
\hline Family Ownership & Family Members' Equity / Total Equity & FAMILY \\
\hline Managerial Ownership & Managers' Equity / Total Equity & MANAGER \\
\hline Foreign Ownership & Foreign Shareholders' Equity / Total Equity & FOREIGN \\
\hline Corporate Ownership & Corporate Shareholders' Equity / Total Equity & CORPORATE \\
\hline Free-Float Rate & Public Equity / Total Equity & FFR \\
\hline \multicolumn{3}{|l|}{ Control Variables } \\
\hline Financial Leverage & Total Assets / Total Equity & LEVERAGE \\
\hline Total Assets & Natural Logarithm of Total Assets & ASSET \\
\hline Age of Bank & Current Year - Founding Year & AGE \\
\hline
\end{tabular}

Source: Authors 
ownership, the largest shareholder's portion, the ownership of the three largest shareholders, and the free-float rate. Herein, the detected control variables of the study are as follows: the financial leverage, the total assets and the age of the bank.

The data used in the study were analyzed by the SPSS program. Durbin-Watson d statistic, VIF (Variance Inflation Factor) and tolerance values were calculated in order to detect autocorrelation and multicollinearity matters. At the end of the computation, no matter was found to be relating to autocorrelation and multicollinearity (Table 2).

Table 2 The equations benefited from in the research

ROAit $=b_{1}$ LARGESTit $+b_{2}$ LARGEST33it $+b_{3}$ FAMILYit $+b_{4}$ MANAGERit $+b_{5}$ FOREIGNit $+b_{6}$ CORPORATEit $+b_{7}$ FFRit + $b_{8}$ LEVERAGEit $+b_{9}$ ASSETit $+b_{10}$ AGEit $+\alpha+\varepsilon_{i t}$

ROEit $=b_{1}$ LARGESTit $+b_{2}$ LARGEST 3 it $+b_{3}$ FAMILYit $+b_{4}$ MANAGERit $+b_{5}$ FOREIGN it $+b_{6}$ CORPORATEit $+b_{7}$ FFRit + $b_{8}$ LEVERAGEit $+b_{9}$ ASSETit $+b_{10}$ AGEit $+\alpha+\varepsilon_{i t}$

TOBINit $=b_{1}$ LARGESTit $+b_{2}$ LARGEST 3 it $+b_{3}$ FAMILYit $+b_{4}$ MANAGERit $+b_{5}$ FOREIGNlit $+b_{6}$ CORPORATEit $+b_{7}$ FFRit + $b_{8}$ LEVERAGEit $+b_{9}$ ASSETit $+b_{10}^{6}$ AGEit $+\alpha+\varepsilon_{i t}$

EPSit $=b_{1}$ LARGESTit $+b_{2}$ LARGEST $3 i t+b_{3}$ FAMILYit $+b_{4}$ MANAGERit $+b_{5}$ FOREIGNit $+b_{6}$ CORPORATEit $+b_{7}$ FFRit + $b_{8}$ LEVERAGEit $+b_{9}$ ASSETit $+b_{10}$ AGEit $+\alpha+\varepsilon_{i t}$

$P /$ Eit $=b_{1}$ LARGESTit $+b_{2}$ LARGEST $3 i t+b_{3}$ FAMILYit $+b_{4}$ MANAGERit $+b_{5}$ FOREICNlit $+b_{6}$ CORPORATEit $+b_{7}$ FFRit + $b_{8}$ LEVERAGEit $+b_{9}$ ASSETit $+b_{10}$ AGEit $+\alpha+\varepsilon_{i t}$

Source: Authors

Furthermore, obtaining reasonable results by carrying out the econometric analyses of the data sets would only be possible if the mentioned data sets were stationary. Hence, stationary tests should be applied before analyzing the data set (Table 3).
Table 3 The results of the panel unit root test

\begin{tabular}{l|cc}
\hline \multicolumn{1}{c|}{ VARIABLES } & \multicolumn{2}{c}{ PP Fisher Test } \\
& Statistic & Probability $(\mathrm{p})$ \\
\hline ROA & 28.32136 & 0.000 \\
ROE & 93.50836 & 0.001 \\
TOBIN & 99.45728 & 0.001 \\
EPS & 27.07877 & 0.005 \\
P/E & 56.96167 & 0.002 \\
ASSET & 64.09028 & 0.000 \\
AGE & 55.21216 & 0.001 \\
LARGEST & 89.5798 & 0.000 \\
LARGEST3 & 59.26537 & 0.000 \\
FAMILY & 53.79758 & 0.005 \\
MANAGER & 34.55004 & 0.000 \\
FOREIGN & 27.9549 & 0.009 \\
CORPORATE & 28.00225 & 0.001 \\
FFR & 30.9971 & 0.001 \\
LEVERAGE & 33.47745 & 0.004 \\
\hline
\end{tabular}

Source: Authors

Due to the fact that correlations existed between the units, the Fisher ADF Unit Root Test was applied in the study. As is seen in the table, the p-values are lower than 0.05 (the critical value). So, the series have no unit root and that the variables are convenient for econometric analysis is suggested.

\section{EMPIRICAL RESULTS}

The descriptive statistics and the empirical results as well indicating the relationship between the bank's ownership structure and its financial performance are shown in this chapter (Table 4).

The descriptive statistics pertaining to the independent, dependent and control variables within the study are indicated in the table. The return-onassets ratio of the banks operating on BIST is about $1.30 \%$. Their return-on-equity ratio, as another indicator for financial performance, is $10 \%$. Tobin's 
$\mathrm{Q}$ ratio, as a market-based financial performance indicator, is $1.45 \%$ on average, their earnings per share are about $0.54 \%$, and their price/earnings ratio is $12.38 \%$ on average.

While the largest shareholder's ownership ratio representing ownership concentration is $59.09 \%$, the rate of the ownership of the three largest shareholders is calculated as $73.77 \%$ on average. The free-float rate of the banks operating on BIST is about $24.48 \%$. the family-ownership ratio is $7.79 \%$, as one of the independent variables representing the ownership identity. Besides, managerial ownership is detected at $0.03 \%$ on average. Additionally, the foreign-ownership ratio as yet another ownership type is $24.67 \%$, and the corporate-ownership rate is about $42.02 \%$.
The Effect of the Ownership Structure Variables on the Return-on-Assets (ROA) Ratio

The results of the analysis indicating the relationship between the banks' ownership structure and their return-on-assets rate are hereinafter accounted for in the Table 5 and Table 6.

Model 1: PROFITABILTY $(\mathrm{ROA})_{i t}=\beta_{1} \quad(.031)$ LARGESTKit $+\beta_{2}(-.093)$ LARGEST3it $+\beta_{3}$ (.095) FAMILYit $+\beta_{4}(-.116)$ MANAGERit $+\beta_{5}(-.016)$ FOREIGNit $+\beta_{6}(-.157)$ CORPORATEit $+\beta_{7}(-.145)$ FFPit $+\beta_{8}(-.327)$ LEVERAGEit $+\beta_{9}(.197)$ ASSETit $+\beta_{10}(-.082)$ $A G E i t+\alpha+\varepsilon_{i t}$

According to the results of the analysis, the ROA ratio is affected by managerial ownership, corporate ownership, the leverage ratio, and the total assets. Managerial ownership has a significant $(5 \%$ level) and negative directional relationship with ROA

Table 4 The descriptive statistics

\begin{tabular}{l|ccccc}
\hline \multicolumn{1}{c|}{ Variables } & $\begin{array}{c}\text { Number of } \\
\text { Observations }\end{array}$ & Mean & Std. Deviation & Min. & Max. \\
\hline ROA & 676 & 1.3094 & 1.76692 & -10.50 & 21.51 \\
ROE & 676 & 10.0021 & 8.03353 & -80.37 & 40.44 \\
TOBIN & 676 & 1.4504 & .76856 & .00 & 4.98 \\
EPS & 676 & .5420 & .45151 & .00 & .90 \\
P/E & 676 & 12.3868 & 13.81257 & .00 & 146.13 \\
ASSET & 676 & 10.3817 & 1.19333 & .00 & 11.56 \\
AGE & 676 & 49.8462 & 22.38359 & 8.00 & 93.00 \\
LARGEST & 676 & 59.0921 & 24.33004 & 17.61 & 100.00 \\
LARGEST3 & 676 & 73.8880 & 16.79675 & 43.84 & 100.00 \\
FAMILY & 676 & 7.7977 & 17.77418 & .00 & 75.00 \\
MANAGER & 676 & .0336 & .14157 & .00 & .63 \\
FOREIGN & 676 & 24.6708 & 36.35622 & .00 & 99.88 \\
CORPORATE & 676 & 42.0287 & 30.57776 & .00 & 99.88 \\
FFR & 676 & 24.4896 & 16.14770 & .00 & 51.10 \\
LEVERAGE & 676 & 8.3621 & 2.43755 & .00 & 16.87 \\
\hline
\end{tabular}

Source: Authors

Table 5 The ROA model sum

\begin{tabular}{ccccccc}
\hline Model & $\mathrm{R}^{2}$ & Adj. $\mathrm{R}^{2}$ & Std. Dev. & $\mathrm{F}$ & Sig. & Durbin-Watson d Statistic \\
\hline ROA & .128 & .115 & 1.66213 & 9.780 & 0.000 & 1.688 \\
\hline
\end{tabular}


Table 6 The ROA regression analysis results

\begin{tabular}{|c|c|c|c|c|c|c|c|}
\hline \multirow[t]{2}{*}{ MODEL ROA } & \multicolumn{2}{|c|}{$\begin{array}{c}\text { Unstandardized } \\
\text { Coefficients }\end{array}$} & \multirow{2}{*}{$\begin{array}{c}\begin{array}{c}\text { Standardized } \\
\text { Coefficients }\end{array} \\
\text { B }\end{array}$} & \multirow[t]{2}{*}{$\mathrm{T}$} & \multirow[t]{2}{*}{ Sig. } & \multicolumn{2}{|c|}{ Collinearity Statistics } \\
\hline & B & Std. Dev. & & & & Tolerance & VIF \\
\hline CONSTANT & 1.944 & .958 & - & 2.030 & $.043^{* *}$ & - & - \\
\hline LARGEST & .002 & .006 & .031 & .377 & .706 & .191 & 5.248 \\
\hline LARGEST3 & -.010 & .012 & -.093 & -.818 & .414 & .101 & 9.927 \\
\hline FAMILY & .009 & .005 & .095 & 1.802 & .072 & .476 & 2.103 \\
\hline MANAGER & -1.448 & .615 & -.116 & -2.356 & $.019^{* *}$ & .540 & 1.850 \\
\hline FOREIGN & -.001 & .003 & -.016 & -.294 & .769 & .448 & 2.233 \\
\hline CORPOR. & -.009 & .003 & -.157 & -3.395 & $.001^{*}$ & .617 & 1.621 \\
\hline FFR & -.016 & .011 & -.145 & -1.491 & .136 & -.138 & 7.221 \\
\hline LEVERAGE & -.237 & .033 & -.327 & -7.171 & $.000^{*}$ & .630 & 1.586 \\
\hline ASSET & .291 & .073 & .197 & 4.008 & $.000 *$ & .544 & 1.838 \\
\hline AGE & -.006 & .005 & -.082 & -1.328 & .185 & .344 & 2.903 \\
\hline
\end{tabular}

$* * 5 \%$ level of significance, ${ }^{*} 1 \%$ level of significance

Source: Authors

(MANAGER $\beta=-.116$; Sig. $=.019$ ). Thus, any increase in the managerial-ownership ratio affects $\mathrm{ROA}$ negatively. Additionally, the corporate- ownership ratio has a significant ( $1 \%$ level) and negative directional relationship with ROA (CORPORATE $\beta=$ -.157; Sig. = .001). Hence, an increase in the corporateownership rate affects ROA negatively. While the leverage ratio has a significant ( $1 \%$ level) and negative directional relationship with ROA (LEVERAGE $\beta=$ -.327 ; Sig. $=.000)$, the total-assets rate has a significant ( $1 \%$ level) and positive directional relationship with the ROA rate (ASSET $\beta=-.197$; Sig. = .000). So, any increase in the leverage ratio affects ROA negatively, whereas any increase in the total assets positively affects the ROA ratio.

\section{The Effect of the Ownership Structure Variables on the Return-on-Equity (ROE) Ratio}

The results of the analysis indicating the relationship between the bank's ownership structure and the return-on-equity (ROE) ratio are presented in the Table 7 and Table 8

Model 2: PROFITABILTY $(\text { ROE })_{i t}=\beta_{1}(.018)$ LARGESTit $+\beta_{2}(-.216)$ LARGEST3it $+\beta_{3}$ (.274)FAMILYit $+\beta_{4}$ $(-.220)$ MANAGERit $+\beta_{5}$ (0.99)FOREIGNit $+\beta_{6}$ (-.058)CORPORATEit $+\beta_{7}(-.208)$ FFRit $+\beta_{8}(-.092)$ LEVERAGEit $+\beta_{9}(.219)$ ASSETit $+\beta_{10}(.088)$ AGEit $+\alpha+$ $\varepsilon_{i t}$

As a result of the carried-out analysis, all variables such as family ownership, managerial ownership, the free-float rate, the leverage ratio, and the total assets

Table 7 The ROE model sum

\begin{tabular}{lllllll}
\hline Model & $\mathrm{R}^{2}$ & Adj. $\mathrm{R}^{2}$ & Std. Dev. & $\mathrm{F}$ & Sig. & Durbin-Watson d Statistic \\
\hline ROE & .100 & .087 & 7.67685 & 7.418 & 0.000 & 1.840 \\
\hline
\end{tabular}


Table 8 The results of the ROE regression analysis

\begin{tabular}{|c|c|c|c|c|c|c|c|}
\hline \multirow{2}{*}{$\begin{array}{l}\text { MODEL } \\
\text { ROA }\end{array}$} & \multicolumn{2}{|c|}{$\begin{array}{c}\text { Unstandardized } \\
\text { Coefficients }\end{array}$} & \multirow{2}{*}{$\begin{array}{c}\begin{array}{c}\text { Standardized } \\
\text { Coefficients }\end{array} \\
\text { B }\end{array}$} & \multirow[t]{2}{*}{$\mathrm{T}$} & \multirow[t]{2}{*}{ Sig. } & \multicolumn{2}{|c|}{ Collinearity Statistics } \\
\hline & $B$ & Std. Dev. & & & & Tolerance & VIF \\
\hline CONSTANT & 5.019 & 4.424 & - & 1.134 & .257 & - & - \\
\hline LARGEST & .006 & .028 & .018 & .220 & .826 & .191 & 5.248 \\
\hline LARGEST3 & -.103 & .055 & -.216 & -1.866 & .062 & .101 & 9.927 \\
\hline FAMILY & .124 & .024 & .274 & 5135 & $.000 *$ & .476 & 2.103 \\
\hline MANAGER & -12.503 & 2.839 & -.220 & -4.404 & $.000 *$ & .540 & 1.850 \\
\hline FOREIGN & .022 & .012 & .099 & 1.795 & .073 & .448 & 2.233 \\
\hline CORPOR. & -.015 & .012 & -.058 & -1.235 & .217 & .617 & 1.621 \\
\hline FFR & -.103 & .049 & -.208 & -2.101 & $.036 * *$ & .138 & 7.221 \\
\hline LEVERAGE & -.304 & .153 & -.092 & -1.992 & $.047^{* *}$ & .630 & 1.586 \\
\hline ASSET & 1.476 & .336 & .219 & 4.397 & $.000 *$ & .544 & 1.838 \\
\hline AGE & .031 & .022 & .088 & 1.400 & .162 & .344 & 2.903 \\
\hline
\end{tabular}

** $5 \%$ level of significance, $* 1 \%$ level of significance

Source: Authors

have an effect on ROE. The family-ownership rate has a significant (1\% level) and positive directional relationship with ROE (FAMILY $\beta=.274$; Sig. $=.000$ ), which implies that any increase in family ownership positively affects the ROE ratio. Managerial ownership shows a significant ( $1 \%$ level), but negative directional relationship with ROE (MANAGER $\beta=$ -.220; Sig. = .000). Hence, an increase in managerial ownership has a negative effect on ROE. A significant (5\% level) and negative directional relationship exists between the free-float rate and ROE (FFR $\beta=-.208$; Sig. $=.036$ ). While the quantity of the shares traded on the stock exchange (the free-float rate) increases, ROE is negatively affected. Besides, the leverage ratio, as one of the control variables, has a significant $(5 \%$ level) and negative directional relationship with ROE (LEVERAGE $\beta=-.092$; Sig. = .047). Finally, a positive directional relationship at a $1 \%$ significance level is found to exist between the total-assets ratio, as another control variable, and the ROE rate (ASSET $\beta=.219$; Sig. $=.000$ ). Therefore, any increase in the leverage ratio means a decrease in $\mathrm{ROE}$, whereas a rise in the total-assets ratio reduces the value of ROE.

\section{The Effect of the Ownership Structure Variables on Tobin's Q (TOBIN) Ratio}

The results of the analysis indicating the relationship between the bank's ownership structure and Tobin's Q ratio are shown in the Table 9 and Table 10:

Model 3: TOBIN'S Q (TOBIN $)_{i t}=\beta_{1} \quad(.264) L A R G E S T i t$ $+\beta_{2}$ (-.250)LARGEST3it $+\beta_{3}$ (.499)FAMILYit $+\beta_{4}$ (-.313)MANAGERit $+\beta_{5}$ (.021)FOREIGNit $+\beta_{6}(-.037)$ CORPORATEit $+\beta_{7}(-.092)$ FFRit $+\beta_{8}(-.132)$ LEVERAGEit $+\beta_{9}(.229)$ ASSETit $+\beta_{10}(-.231)$ AGEit $+\alpha+\varepsilon_{i t}$

Table 9 Tobin's Q ratio model sum

\begin{tabular}{lllllll}
\hline Model & $\mathrm{R}^{2}$ & Adj. $\mathrm{R}^{2}$ & Std. Dev. & $\mathrm{F}$ & Sig. & Durbin-Watson d Statistic \\
\hline Tobin's Q & .255 & .243 & .66855 & 22.707 & .000 & 1.846 \\
\hline
\end{tabular}


Table 10 Tobin's $\mathrm{Q}$ ratio regression analysis results

\begin{tabular}{|c|c|c|c|c|c|c|c|}
\hline \multirow{2}{*}{$\begin{array}{l}\text { MODEL } \\
\text { Tobin's Q }\end{array}$} & \multicolumn{2}{|c|}{$\begin{array}{l}\text { Unstandardized } \\
\text { Coefficients }\end{array}$} & \multirow{2}{*}{$\begin{array}{c}\text { Standardized } \\
\text { Coefficients } \\
\text { B }\end{array}$} & \multirow[t]{2}{*}{$\mathrm{T}$} & \multirow[t]{2}{*}{ Sig. } & \multicolumn{2}{|c|}{ Collinearity Statistics } \\
\hline & B & Std. Dev. & & & & Tolerance & VIF \\
\hline CONSTANT & 1.039 & .385 & - & 2.697 & $.007^{*}$ & - & - \\
\hline LARGEST & .008 & .002 & .264 & 3.438 & $.001 *$ & .191 & 5.248 \\
\hline LARGEST3 & -.011 & .005 & -.250 & -2.365 & $.018 * *$ & .101 & 9.927 \\
\hline FAMILY & .022 & .002 & .499 & 10.271 & $.000 *$ & .476 & 2.103 \\
\hline MANAGER & -1.699 & .247 & -.313 & -6.870 & $.000 *$ & .540 & 1.850 \\
\hline FOREIGN & .000 & .001 & .021 & .429 & .668 & .448 & 2.233 \\
\hline CORPOR. & -.001 & .001 & -.037 & -.877 & .381 & .617 & 1.621 \\
\hline FFR & -.004 & .004 & -.092 & -1.025 & .306 & .138 & 7.221 \\
\hline LEVERAGE & -.042 & .013 & -.132 & -3.134 & $.002 *$ & .630 & 1.586 \\
\hline ASSET & .148 & .029 & .229 & 5.048 & $.000 *$ & .544 & 1.838 \\
\hline AGE & -.008 & .002 & -.231 & -4.058 & $.000 *$ & .344 & 2.903 \\
\hline
\end{tabular}

$*_{5} \%$ level of significance, ${ }^{*} \%$ level of significance

Source: Authors

According to the results of the analysis, Tobin's Q (TOBIN) ratio is affected by family ownership, managerial ownership, the largest shareholder's ownership, the ownership of the three largest shareholders, the leverage ratio, the total assets and the age of the bank variables. Herein, family ownership has a significant (1\% level) and positive directional relationship with Tobin's Q ratio (FAMILY $\beta=.499$; Sig. $=.000)$; hence, an increase in the familyownership ratio causes a rise in Tobin's $Q$ rate. Managerial ownership has a significant ( $1 \%$ level), but negative directional relationship with Tobin's $\mathrm{Q}$ ratio (MANAGER $\beta=-.313$; Sig. $=.000$ ). So, an increase in managerial ownership means a decrease in Tobin's $\mathrm{Q}$ ratio. A positive directional relation at a $1 \%$ significance level is detected between the largest shareholder's ownership and Tobin's Q ratio (LARGEST $\beta=.264$; Sig.= .001), which means that an increase in the largest shareholder's ownership causes a rise in Tobin's Q ratio. The ownership of the three largest shareholders has a significant (5\% level) and negative directional relationship with Tobin's Q ratio (LARGEST3 $\beta=-.250$; Sig. = .018). Therefore, Tobin's $Q$ ratio would decrease in the case of an increase in the ownership of the three largest shareholders. As one of the control variables, the leverage ratio has a negative directional relationship with Tobin's $Q$ ratio at a $1 \%$ significance level (LEVERAGE $\beta=-.132$; Sig. = .002). Besides, the total-assets rate, as another control variable, has a significant ( $1 \%$ level) and positive directional relationship with Tobin's Q ratio (ASSET $\beta=.229$; Sig. $=.000$ ). Also, as the last control variable, the age-of-a-bank variable has a significant (1\% level) and negative directional relationship with Tobin's Q ratio (AGE $\beta=-.231$; Sig. $=.000$ ). Thus, an increase in the leverage and age variables causes a decrease in Tobin's Q ratio, whereas an increase in the total assets positively affects Tobin's $Q$ ratio.

\section{The Effect of the Ownership Structure Variables on the Earnings-per-Share (EPS) Ratio}

The results of the analysis indicating the relationship between the bank's ownership structure and the earnings-per-share (HBK) ratio are shown in the Table 11 and Table 12.

Model 4: EARNINGS PER SHARE (EPS) ${ }_{i t}=\beta 1$ (.595) LARGESTit $+\beta_{2}(-.484)$ LARGEST3it $+\beta_{3}(.069)$ FAMILYit $+\beta_{4}(-.143)$ MANAGERit $+\beta_{5}(.448)$ FOREIGNit $+\beta_{6}(-.409)$ CORPORATEit $+\beta_{7}(.124)$ FFRit $+\beta_{8}(-.011)$ LEVERAGEit $+\beta_{9}(.241)$ ASSETit $+\beta_{10}(-.452) A G E i t+\alpha+\varepsilon_{\text {it }}$ 
Table 11 The earnings per share (EPS) model sum

\begin{tabular}{ccccccc}
\hline Model & $\mathrm{R}^{2}$ & Adj. $\mathrm{R}^{2}$ & Std. Dev. & $\mathrm{F}$ & Sig. & Durbin-Watson d Statistic \\
\hline EPS & .480 & .472 & .32801 & 61.398 & .000 & 1.758 \\
\hline
\end{tabular}

Source: Authors

Table 12 The earnings per share regression analysis results

\begin{tabular}{|c|c|c|c|c|c|c|c|}
\hline \multirow{2}{*}{$\begin{array}{c}\text { MODEL } \\
\text { EPS }\end{array}$} & \multicolumn{2}{|c|}{$\begin{array}{l}\text { Unstandardized } \\
\text { Coefficients }\end{array}$} & \multirow{2}{*}{$\begin{array}{c}\text { Standardized } \\
\text { Coefficients }\end{array}$} & \multirow[t]{2}{*}{$\mathrm{T}$} & \multirow[t]{2}{*}{ Sig. } & \multicolumn{2}{|c|}{ Collinearity Statistics } \\
\hline & $B$ & Std. Dev. & & & & Tolerance & VIF \\
\hline CONSTANT & -.499 & .189 & - & -2.642 & $.008 *$ & - & - \\
\hline LARGEST & .011 & .001 & .595 & 9.294 & $.000 *$ & .191 & 5.248 \\
\hline LARGEST3 & -.013 & .002 & -.484 & -5.492 & $.000 *$ & .101 & 9.927 \\
\hline FAMILY & .002 & .001 & .069 & 1.694 & .091 & .476 & 2.103 \\
\hline MANAGER & -.455 & .121 & -.143 & -3.748 & $.000 *$ & .540 & 1.850 \\
\hline FOREIGN & .006 & .001 & .448 & 10.726 & $.000 *$ & .448 & 2.233 \\
\hline CORPOR. & -.006 & .001 & -.409 & -11.491 & $.000 *$ & .617 & 1.621 \\
\hline FFR & .003 & .002 & .124 & 1.654 & .099 & .138 & 7.221 \\
\hline LEVERAGE & -.002 & .007 & -.011 & -.316 & .752 & .630 & 1.586 \\
\hline ASSET & .091 & .014 & .241 & 6.349 & $.000 *$ & .544 & 1.838 \\
\hline AGE & .009 & .001 & .452 & 9.490 & $.000 *$ & .344 & 2.903 \\
\hline
\end{tabular}

$* * 5 \%$ level of significance, $* 1 \%$ level of significance

Source: Authors

As a result of the analysis, the earnings-per-share ratio is affected by the variables such as managerial ownership, foreign ownership, corporate ownership, the largest shareholder's ownership, the ownership of the three largest shareholders, the total assets and the age of the bank. Managerial ownership has a significant ( $1 \%$ level) and negative directional relationship with earnings per share (EPS) (MANAGER $\beta=-.143$; Sig. = .000). So, an increase in managerial ownership causes a decline in the earnings-per-share (EPS) value. The foreign-ownership variable has a significant $(1 \%$ level) and positive directional relationship with earnings per share (FOREIGN $\beta=.448$; Sig. $=.000$ ). Thus, as the foreign-ownership value increases, the value of earnings per share (EPS) increases as well. Additionally, a negative directional relationship at a $1 \%$ significance level is detected between corporate ownership and earnings per share (CORPORATE $\beta$ $=-.409$; Sig. $=.000$ ). Hence, an increase in corporate ownership means a decline in the earnings-per-share (EPS) value. The largest shareholder's ownership, one of the variables representing ownership concentration, has a significant ( $1 \%$ level) and positive directional relationship with earnings per share (LARGEST $\beta=.595$; Sig. $=.000$ ). Furthermore, the ownership of the three largest shareholders, as another variable representing ownership concentration, has a significant ( $1 \%$ level), but negative directional relationship with earnings per share (LARGEST3 $\beta$ $=-.484$; Sig. $=.000)$. Finally, each of the ratios of the total assets and the age of a bank representing the control variables herein has a positive directional and significant relationship at a $1 \%$ level with the earnings-per-share (EPS) rate (ASSET $\beta=.241$; Sig. = $.000)$, and (AGE $\beta=.452$; Sig. $=.000)$, too. 


\section{The Effect of the Ownership Structure Variables on the Price/Earnings (P/E) Ratio}

The results of the analysis indicating the relationship between the bank's ownership structure and the Price/Earnings ratio $(\mathrm{F} / \mathrm{K})$ are shown in the Table 13 and Table 14.

Model 5: PRICE/EARNINGS RATIO $(\mathrm{P} / \mathrm{E})_{i t}=\beta_{1}(.157)$ LARGESTit $+\beta_{2}(.140)$ LARGEST3it $+\beta_{3}(-.043)$ FAMILYit $+\beta_{4}(.013)$ MANAGERit $+\beta_{5}(-.166)$ FOREIGNit $+\beta_{6}(-.048)$ CORPORATEit $+\beta_{7}(.140)$ FFR it $+\beta_{8}(-.221)$ LEVERAGEit $+\beta_{9}(.117)$ ASSETit $+\beta_{10}(-.378)$ AGEit $+\alpha+\varepsilon_{i t}$

According to the obtained results, each of the variables such as the largest shareholder's ownership, foreign ownership, the leverage ratio, the total assets, and the age of a bank has an effect on the price/earnings $(\mathrm{P} / \mathrm{E})$ ratio. The largest shareholder's ownership, as one of the ownership concentration variables, has a significant ( $5 \%$ level) and positive directional relationship with the price/earnings ratio (LARGEST $\beta=.157$; Sig. $=.049$ ). A negative directional relationship at a $1 \%$ significance level is detected between foreign ownership and the price/earnings ratio (FOREIGN $\beta=-.166$; Sig. = .001). Thus, an increase in foreign ownership within the capital structure causes a decrease in the price/earnings $(\mathrm{P} / \mathrm{E})$ ratio. The leverage ratio, as one of the control variables, has a significant ( $1 \%$ level) and negative directional relationship with the price/earnings ratio (LEVERAGE $\beta=-.221$; Sig. $=.000$ ). A positive directional relationship at a $5 \%$ significance level is found to exist between the total assets and the price/earnings ratio (ASSET $\beta=.117$; Sig. $=.013$ ) beside a negative directional relationship at a $1 \%$ significance level, which is detected between the age variable and the price/earnings ratio (AGE $\beta=-.378$; Sig. $=.000$ ). Therefore, any increase in the leverage and age variables causes a decline in the

Table 13 The price/earnings ratio $(\mathrm{P} / \mathrm{E})$ model sum

\begin{tabular}{ccccccc}
\hline Model & $\mathrm{R}^{2}$ & Adj. $\mathrm{R}^{2}$ & Std. Dev. & $\mathrm{F}$ & Sig. & Durbin-Watson d Statistic \\
\hline $\mathrm{P} / \mathrm{E}$ & .197 & .185 & 12.47241 & 16.285 & .000 & 1.901 \\
\hline
\end{tabular}

Source: Authors

Table 14 The price/earnings ratio $(\mathrm{P} / \mathrm{E})$ regression analysis results

\begin{tabular}{|c|c|c|c|c|c|c|c|}
\hline \multirow{2}{*}{$\begin{array}{c}\text { MODEL } \\
\text { P/E }\end{array}$} & \multicolumn{2}{|c|}{$\begin{array}{l}\text { Unstandardized } \\
\text { Coefficients }\end{array}$} & \multirow{2}{*}{$\begin{array}{c}\begin{array}{c}\text { Standardized } \\
\text { Coefficients }\end{array} \\
\text { B }\end{array}$} & \multirow[t]{2}{*}{$\mathrm{T}$} & \multirow[t]{2}{*}{ Sig. } & \multicolumn{2}{|c|}{ Collinearity Statistics } \\
\hline & B & Std. Dev. & & & & Tolerance & VIF \\
\hline CONSTANT & 6.414 & 7.188 & - & .892 & .373 & - & - \\
\hline LARGEST & .089 & .045 & .157 & 1.972 & $.049^{* *}$ & .191 & 5.248 \\
\hline LARGEST3 & .115 & .090 & .140 & 1.275 & .203 & .101 & 9.927 \\
\hline FAMILY & -.033 & .039 & -.043 & -.849 & .396 & .476 & 2.103 \\
\hline MANAGER & 1.260 & 4.613 & .013 & .273 & .785 & .540 & 1.850 \\
\hline FOREIGN & -.063 & .020 & -.166 & -3.199 & $.001 *$ & .448 & 2.233 \\
\hline CORPOR. & -.022 & .020 & -.048 & -1.090 & .276 & .617 & 1.621 \\
\hline FFR & .120 & .080 & .140 & 1.504 & .133 & .138 & 7.221 \\
\hline LEVERAGE & -1.250 & .248 & -.221 & -.5039 & $.000^{*}$ & .630 & 1.586 \\
\hline ASSET & 1.352 & .545 & .117 & 2.479 & $.013^{* *}$ & .544 & 1.838 \\
\hline AGE & -.233 & .037 & -.378 & -6.376 & $.000 *$ & .344 & 2.903 \\
\hline
\end{tabular}

$* *_{5} \%$ level of significance, ${ }^{*} \%$ level of significance

Source: Authors 
price/earnings $(\mathrm{P} / \mathrm{E})$ ratio, whereas the total-assets ratio positively affects the price/earnings variable.

\section{Results}

The relationship between the ownership structure and financial performance in the case of the banks operating on the Istanbul Stock Exchange (BIST) was analyzed in this study. The quarterly regular data of the 13 banks listed on BIST were applied, pertaining to the 2005-2017 period, and 52 terms were included in the study. The financial performance indicators used in the study are as follows: return on assets (ROA), return on equity (ROE), Tobin's $Q$ ratio (TOBIN), earnings per share (EPS), and the price/earnings $(\mathrm{P} / \mathrm{E})$ ratio. The selected independent variables of the study are as follows: family ownership, corporate ownership, managerial ownership, foreign ownership, the largest shareholder's ownership, the ownership of the three largest shareholders, and the free-float rate. According to the results obtained after carrying out the analysis, the ownership structure variables affect the financial performance indicators of banks.

While family ownership has a positive directional relationship with $\mathrm{ROE}$ (as one of the financial performance indicators), managerial ownership has negative directional relationships with both $\mathrm{ROA}$ and ROE. The results suggest that agency theory is supported. The cited theory points out a possible conflict between shareholders and managers, mentioning thus a decision-making problem a firm's managers are faced with due to their own interests. As a result of the performed analysis, an increase in managerial ownership means lower profitability, which is supportive of the mentioned theory. The economic, legal, sociocultural and historical structures are substantial within the countries' corporate governance practices. Legal protection standards are evaluated as satisfactory for developed economies, and ownership spreads across the country. Because of the poor structure of legal protection within developing countries like Turkey, the family ownership and concentrated ownership structures are put forward. Hence, the positive relationship detected between family ownership and ROE is also supportive of agency theory. Tobin's $\mathrm{Q}$ ratio is formulated as a market value/book value in the study; additionally, a positive directional relationship is found to exist between family ownership and Tobin's Q ratio. Banks in family ownership expect to attract foreign investors by raising their market prices. Thus, an increase in Tobin's Q ratio owing to family ownership is reasonable. Similar results were obtained in the literature in the studies by E. Berezneak (2007), and M. R. King and E. Santor (2008). Besides, managerial ownership has negative directional relationships with Tobin's $Q$ ratio and the earnings-per-share (EPS) rate. C. P. Himmelberg, R. G. Hubbard and D. Palia (1999) investigated the topic for developing countries and came to similar results. In spite of the noteworthy relationship revealed between managerial ownership and financial performance, expanding this claim in the context of Turkey's banking sector has not proven to be satisfactory yet. According to the results of the study, corporate ownership demonstrates negative directional relationships between return on assets (ROA) and earnings per share (EPS). Though higher financial performance is expected through a rise in corporate investors' corporate management practices, various results have been obtained based on the recently-conducted studies. Corporate investors' financial performances are related to the legal protection level, regulations, accounting system, etc. of the country they operate in. Hence, the influence of corporate investors on financial performance might probably be expected in the economies with developed corporate management practices. The existence of a poor legal protection level in developing countries like Turkey hinders the expected effect on the financial performance of the corporate investors. A negative directional relationship is detected between the free-float rate and return on equity (ROE), which supports agency theory. Due to an increase in the free-float rate, agency costs arise, and agents could tend to pursue their own interests. Hence, the mentioned situation has a negative effect on financial performance. I. Sakınç (2008), and E. E. Topaloğlu, N. Coşkun and C. Özkan (2016) came to similar results in the study aimed at this topic. It is suggested that corporate management practices should be enhanced and minority rights should be strengthened in Turkey 
in order to increase the positive effect of the free-float rate on financial performance. Foreign ownership has a positive directional relationship with earnings per share (EPS), and a negative relationship with the price/earnings $(\mathrm{P} / \mathrm{E})$ ratio. Investors expecting to gain share profits from banks are to invest in foreign dominant banks, because banks in foreign ownership are supposed to have higher financial performance due to their better corporate management practices. The findings in the context of Turkey, however, do not support this statement. The corporate management grade and the poor legal protection level in Turkey affect the mentioned situation. Therefore, corporate management practices should be developed in Turkey. Regarding the topic, quite separate results have recently been obtained from the literature. Differences between countries have an effect on the financial performances of foreign investors. The largest shareholder's ownership has positive relationships with Tobin's Q ratio, the earnings-pershare (EPS) and price/earnings rates (P/E). Besides, the ownership of the three largest shareholders has negative relationships with Tobin's $Q$ ratio and earnings per share (EPS). So, concentration increases in the ownership structures of banks (when the ownership structure does not spread to the base) positively affect financial performance. Financial performance increases in the structures characterized by the existence of a single person's or corporation's dominance. It is suggested that these results support agency theory. The concentration occurring in the ownership structure removes the separation of ownership and control; thus, the main shareholder becomes the manager and the controller. Hereby, this situation could reduce agency costs and losses.

According to the results of the study, each ownership structure has an effect on the financial performances of the banks operating on BIST. These results prove the hypotheses of the research.

\section{CONCLUSION}

This study was conducted for the quarterly time period between 2005 and 2017, for the 13 banks operating on the Istanbul Stock Exchange. A total of 52 terms were analyzed, and 676 observations were obtained. The mentioned banks-pertaining data were obtained through annual reports, independent audit reports, the Finnet financial analysis program and the Central Securities Depository (CSD) of Turkey. These are the basic research limitations of the study.

The mentioned results point out that the corporate governance approach, hence the ownership structure and financial performance relationships, could vary from one country to another. Countries' corporate

Table 15 The hypotheses statement table

\begin{tabular}{|c|c|c|c|}
\hline $\begin{array}{l}\text { Number of } \\
\text { Hypothesis }\end{array}$ & Hypothesis & Test Applied & Accept/Reject \\
\hline $\mathrm{H} 1$ & $\begin{array}{l}\text { The ownership structure has an effect on a bank's } \\
\text { return-on-assets ratio. }\end{array}$ & Multiple Regression & Accepted \\
\hline $\mathrm{H}_{2}$ & $\begin{array}{l}\text { The ownership structure has an effect on a bank's } \\
\text { return-on-equity ratio. }\end{array}$ & Multiple Regression & Accepted \\
\hline $\mathrm{H}_{3}$ & $\begin{array}{l}\text { The ownership structure has an effect on Tobin's Q } \\
\text { ratio. }\end{array}$ & Multiple Regression & Accepted \\
\hline $\mathrm{H}_{4}$ & $\begin{array}{l}\text { The ownership structure has an effect on the earnings- } \\
\text { per-share ratio. }\end{array}$ & Multiple Regression & Accepted \\
\hline $\mathrm{H}_{5}$ & $\begin{array}{l}\text { The ownership structure has an effect on a bank's } \\
\text { price/earnings ratio. }\end{array}$ & Multiple Regression & Accepted \\
\hline
\end{tabular}


governance practices lead to a variation in the relationships between their economic structures, regulations, legal protection level, ownership structures and financial performances. Better corporate management practices and an advanced legal protection level are what Turkey needs so as to increase financial performance within the banking sector. Therefore, other foreign investors could be attracted by Turkey, and they could be included in the banking system via ownerships. Herein, it is suggested that ownership concentration within the banking sector represents a barrier for achieving the optimal capital structure. In the case of spreading capital to the base and having more shareholders for banks, it could contribute to the development of corporate management practices.

The results obtained are supposed to be of substantial importance to the top managers of banks, investors, the regulators operating in financial markets, and researchers as well. This study could be a benchmark to form better management models between stockholders regarding ownership structures, managers and other groups in the context of a corporate management approach. So, and especially regarding managers, the key question is: "What is better corporate governance?". The results of the study are supposed to lead to critical decision, such as new partnerships and IPOs, for banks. Besides, they could also contribute to the reforms of bank managers, aiming to optimize their relationships with stakeholders, which means that the banks listed on BIST could benefit from this research study in the sense of their being guided within this framework.

Finally, academics can examine different types of relationships between the ownership structure and financial performance in future studies, which will contribute to achieving better corporate governance.

\section{REFERENCES}

Antoniadis, I., Lazarides, T., \& Sarrianides, N. (2010, January). Ownership and performance in the Greek banking sector. Paper presented at the International Conferance on Applied Economics.
Berezneak, E. (2007). Kurumsal Yönetim Çerçevesinde Sahiplik Yapısı ve Performans İlişkisi: Türkiye Uygulaması. Unpublished master thesis. Yıldız Teknik University, Istanbul, Turkey.

Berle, A. A., \& Means, C. G. (1932). The Modern Corporation and Private Property. New York, NY: Harcourt Brace and World Inc.

Bokpin, G. A. (2013). Ownership structure, corporate governance and bank efficiency: An emprical analysis of panel data from the banking industry in Ghana. Corporate Governance, 13(3), 274-287. doi.org/10.1108/CG-05-2010-0041

Denis, D. K., \& McConnell, J. J. (2003). International corporate governance. The Journal of Financial and Quantitative Analysis, 38(1), 1- 36. doi.org/10.2307/4126762

Elitaş, B. L, Doğan, M., \& Kevser, M. (2017). Finansal sıkıntı ve sahiplik yapısı arasındaki ilişki: Borsa İstanbul üzerine bir araştırma. İsletme Araştırmaları Dergisi, 9(4), 787-804.

Grob, K. (2006). Equity Ownership and Performance: An Emprical Study of German Traded Companies. New York, NY: Physica Verlag A Springer Company.

Himmelberg, C. P., Hubbard, R. G., \& Palia, D. (1999). Understanding the determinants of managerial ownership and the link between ownership and performance. Journal of Financial Economics, 53(3), 353-384.

İzciler, D. (2014). Kurumsal Yönetim İlkelerine Uyum Sürecinin Şirketlerin Performansları Üzerine Etkileri. Unpublished master thesis, Marmara University, Istanbul, Turkey.

King, M. R., \& Santor, E. (2008). Family values: Ownership structure, performance and capital structure of Canadian firms. Journal of Banking and Finance, 32(11), 2423-2432.

Kiruri, R. M. (2013). The effects of ownership structure on bank profitability in Kenya. European Journal of Management Sciences and Economics, 1(2), 116-127.

Kobeissi, N., \& Sun, X. (2010). Ownership structure and bank performance: Evidence from the middle East and North Africa region. Comparative Economic Studies, 52(3), 287-323.

Kosak, M., \& Cok, M. (2008). Ownership structure and profitability of the banking sector: The evidence from the SEE region. Journal of Economics and Business, 26(1), 93-122.

Micco, A., Panizza, U., \& Yañez, M. (2004). Bank ownership and performance. IDB Working Paper No. 429. doi. org/10.2139/ssrn.1818718 
Nguyen, H. S., Tran, T. T. T., Dinh, X. C., Lai, A. N., \& Pham, B. K. (2015). Impact of ownership structure and bank performance-an emprical test in Vietnamese Banks. International Journal of Financial Research, 6(4), 123-133. doi:10.5430/ijfr.v6n4p123

Sakınç, İ. (2008). Sermaye Sahipliği ve Firma Değeri İle İlişkisi. Unpublished doctoral thesis, Gazi University, Ankara, Turkey.

Tanriöven, C., Küçükkaplan, İ., \& Başçı, E. S. (2006). Kurumsal yönetim açısından sahiplik ve kontrol yapısı ile üst düzey yönetici durumunun IMKB'de faaliyet gösteren bankalarda incelenmesi. Iktisat, Işletme ve Finans Dergisi, 21(241), 87-104.
Topaloğlu, E. E., Coşkun, N., \& Özkan, C. (2016). Sahiplik yapısı ile finansal performans arasındaki ilişkinin Borsa İstanbul 30 endeksi'ndeki şirketlerde test edilmesi. Finans Politik \& Ekonomik Yorumlar, 53(620), 85-107.

Tükenmez, N. M., Gençyürek, A. G., \& Kabakcı, C. Ç. (2016). Türk bankacılık sektöründe sahiplik yoğunlaşması ile finansal performans ilişkisinin incelenmesine yönelik ampirik bir çalışma. Atatürk Üniversitesi İktisadi ve İdari Bilimler Dergisi, 30(3), 625-644.

Wen, W. (2010). Ownership structure and banking performance: New evidence in China. Europen Doctoral Programme in Entrepreneurship and Small Business Management. Research Work, 1-42.

Received on $24^{\text {th }}$ March 2019, after revision, accepted for publication on $20^{\text {th }}$ August 2019 Published online on $23^{\text {rd }}$ August 2019

Bilge Leyli Elitaş is an associate professor at the University of Yalova, Faculty of Economics and Administrative Sciences, International Trade and Finance Department, The Republic of Turkey. She teaches the following courses: Financial Accounting, Cost Accounting, Analysis of Financial Statements. Her main research areas include accounting, auditing, tax and international finance theories.

Mustafa Kevser is an assistant professor at Manyas Vocational School, Bandirma Onyedi Eylul University, Turkey. His main research areas include financial markets and institutions, financial performance, banking and corporate governance. 


\title{
ODNOS IZMEĐU VLASNIČKE STRUKTURE BANAKA I FINANSIJSKOG POSLOVANJA: EMPIRIJSKO ISTRAŽIVANJE ZA TURSKU
}

\author{
Mustafa Kevser and Bilge Leyli Elitaş \\ Faculty of Economics and Administrative Sciences, Yalova, Turkey
}

Cilj ove studije je analiza efekata vlasničke strukture banaka na njihovo finansijsko poslovanje. Korišćeni su kvartalni podaci za 13 banaka koje se kotiraju na istambulskoj Berzi (BIST), a koji se odnose na period 2005-2017. Kao indikatori finansijskog poslovanja, u studiji se koriste prinos na ukupno angažovana sredstva (ROA), prinos na akcijski kapital (ROE), Tobinov Q-koeficijent (TOBIN), zarada po akciji (EPS), i koeficijent cene i čiste dobiti (P/E koeficijent). Porodično vlasništvo, korporativno vlasništvo, menadžersko vlasništvo, inostrano vlasništvo, vlasništvo najvećeg akcionara, vlasništvo tri najveća akcionara, i stopa slobodnog fluktuiranja su opredeljeni kao nezavisne varijable za izvođenje ove studije, dok su koeficijent zaduženosti, ukupna aktiva i godine poslovanja banke opredeljeni kao kontrolne varijable. Formirano je pet modela za analizu odnosa između varijabli i sprovedena je regresiona analiza. Analize su pokazale da vlasničke strukture banaka utiču na njihovo finansijsko poslovanje. Osim toga, sugeriše se da su rezultati dobijeni analizama koherentni za teoriju agencije, kao jednu od fundamentalnih teorija koje se bave ovim predmetom.

Ključne reči: vlasnička struktura, finansijsko poslovanje, teorija agencije, bankarstvo, korporativno upravljanje

JEL Classification: G10, G32 